\title{
Optic Nerve Cysticercosis at the Orbital Apex
}

\author{
Mahmood Dhahir Al-Mendalawi, MB, CH.B, DCH, FICMS \\ Department of Paediatrics, Al-Kindy College of Medicine, University of Baghdad, Baghdad, Iraq \\ ORCID: \\ Mahmood Dhahir Al-Mendalawi: https://orcid.org/0000-0003-2872-453X
}

J Ophthalmic Vis Res 2020; 15 (1): 121-121

Dear Editor,

I read with interest the case report by Goel ${ }^{[1]}$ published in the October-December 2018 issue of the Journal of Ophthalmic and Vision Research. The author described nicely a case of optic nerve cysticercosis at the orbital apex presenting as optic neuritis in an Indian patient. ${ }^{[1]}$ It is wellknown that due to compromised immune system, individuals infected with human immunodeficiency virus (HIV) are more susceptible to various types of viral, bacterial, fungal, and parasitic infections compared to the individuals with healthy immune system. Among parasitic infections, cysticercosis has been reported among HIV-positive patients. ${ }^{[2]}$ To my knowledge, HIV infection is a distressing health issue in India. The available data pointed out to $0.26 \%$ HIV seroprevalence compared with a global average of $0.2 \%,{ }^{[3]}$ and the overall seropositivity for cysticercosis was reported to be $5 \%$ among HIV-positive patients in India. ${ }^{[4]}$ । assume that the underlying HIV infection ought to be taken into consideration in the studied patient. Accordingly, planning for the diagnostic battery of blood CD4 count and viral overload measurements for HIV infection was envisaged. If that battery was contemplated and it disclosed HIV reactivity, the case in question could be obviously regarded the second novel case report

This is an open access journal, and articles are distributed under the terms of the Creative Commons Attribution-NonCommercial-ShareAlike 4.0 License, which allows others to remix, tweak, and build upon the work non-commercially, as long as appropriate credit is given and the new creations are licensed under the identical terms.

Correspondence to:

Mahmood Dhahir Al-Mendalawi, MB, CH.B, DCH, FICMS. Baghdad 55302, Iraq.

E-mail: mdalmendalawi@yahoo.com

Received: 25-11-2018 Accepted: 25-01-2019 of HIV-associated orbital cysticercosis in India. The first report was of subretinal cysticercosis in an Indian patient with AIDS reported nearly two decades ago. ${ }^{[5]}$

\section{Financial Support and Sponsorship}

Nil.

\section{Conflicts of Interest}

There are no conflicts of interest.

\section{REFERENCES}

1. Goel N. Optic nerve cysticercosis at the orbital apex presenting as optic neuritis. J Ophthalmic Vis Res 2018;13:508-510.

2. Chianura L, Sberna M, Moioli C, Villa MR, Orcese C, Causarano R. Neurocysticercosis and human immunodeficiency virus infection: a case report. J Travel Med 2006;13:376-380.

3. Paranjape RS, Challacombe SJ. HIV/AIDS in India: an overview of the Indian epidemic. Oral Dis 2016;22:10-14.

4. Parija SC, Gireesh AR. A serological study of cysticercosis in patients with HIV. Rev Inst Med Trop Sao Paulo 2009;51:185-189.

5. George AE, Biswas J, Agarwal R, Kumarasamy N, Solomon S. Subretinal cysticercosis in a patient with AIDS: treatment with xenon arc photocoagulation. Retina 1999;19:467468.

\begin{tabular}{|l|}
\hline \multicolumn{1}{|c|}{ Access this article online } \\
\hline Website: https://knepublishing.com/index.php/JOVR \\
\hline DOI: $10.18502 /$ jovr.v15i1.5965 \\
\hline
\end{tabular}

How to cite this article: Al-Mendalawi MD. Optic Nerve Cysticercosis at the Orbital Apex. J Ophthalmic Vis Res 2020;15:121-121. 